\title{
$\mathbf{X}$ 線露光用位置合わせ法の研究*
}

石原直**

Mask Alignment Method for X-Ray Lithography

\section{Sunao IsHIHARA}

To achieve accurate pattern registration in proximity printing with divergent $\mathrm{X}$-rays, three dimensional geometrical analysis of registration error factors has been carried out theoretically. Analysis shows that pattern registration is achieved by controlling the relative displacements of mask and wafer along six axes; shifts $x$ and $y$, rotation $\theta$, spacing $z$, and inclinations $\alpha$ and $\beta$, and that the positioning accuracy required in the each vertical direction can be reduced by a factor of $R / D$, compared with the horizontal positioning, where $R$ is

\section{1. は じめに}

Si ウエハ上飞微細なパタンを形成するマイクロ加工 技術は，VLSI 実現のための重要な基礎技術の一つであ る. 中でも, 高精度でパタン創成の可能な電子線でマス クを作り，解像力の高いX線でウェ八に転写する加工法 は, 生産性の高い微細パタン形成が期待できる.

軟 X線を用いるリソグラフィ技術は, 1972 年に MIT のSmith らが提案1) して以来, 各方面で解析, 実験が 行われ，高解像性，耐じん性などの優れた特長が確認さ れている.しかしながら，これまでの応用例は，比較的 小さい露光面積でマスク合わせの容易な表面弾性波素子 や磁気バブル素子に集中し，半導体デバイスへの応用例 は少ない，これは，広い面積にわたっての解像力に見合 らパタン合わせの技術が一つのネックとなっていたため である.

リソグラフィに抢汸午タン合わせ精度は, 経験的に 線幅の $1 / 5$ とされ, 最小線幅 $1 \mu \mathrm{m}$ のパタン転写を目標 とすると, 合わせ精度として $\pm 0.2 \mu \mathrm{m}$ が要求される. そして, 発散光を用いてプロキシミティ露光を行ら $\mathrm{X}$ 線 露光では，X線光軸方向も含めた立体的位置合わせが必

* 原稿受付 昭和 54 年 11 月 16 日.昭和 51 年度精機学会秋 季大会学術講演会（昭和 51 年 10 月 13 日）および昭和 52 年度精機学会秋季大会学術講演会(昭和 52 年 10 月 17 日) ならびに昭和 53 年度精機学会秋季大会学術講演会（昭和 53 年 10 月 4 日）にて発表.

** 正会員 日本電信電話公社武蔵野電気通信研究所(武蔵 野市緑町 3-9-11) wafer radius and $D$ is exposure distance. It is also shown that isotropic wafer distortion can be corrected by proximity gap control, just as a run-out error. According to these considerations, an alignment system has been developed utilizing a six degree of freedom positioner, electro-static gap detectors, photo-electric mark detectors and micro-computer software. The system ability for pattern registration has been evaluated by experimental exposures at an error of less than $\pm 0.2 \mu \mathrm{m}$, which is sufficient for fabricating devices with $1 \mu \mathrm{m}$ design rules.

Key words: mask alignment, X-ray lithography, pattern registration, geometrical analysis, alignment system.

要である.これまで,このような位置合わせ法について 系統的に論じた報告は見当たらない，また，X線露光用 のマスク合わせ法として， McCoy らがX 線を用いる方 法2), Flanders らが回折格子による方法3)などを提案し ているが,いずれも実験室段階のものにとどまっている.

本論文は, $\mathrm{X}$ 線露光法関する総合的な研究4)5) の中 で, マスク, ウェ八位置合わせ法についての基本的考察 と，それに基づく位置合わせ装置の試作結果の報告であ る.

\section{2. 位置ずれ誤差要因の解析}

$\mathrm{X}$ 線露光では, プロキシミティ露光でも高い解像力が 得られることが大きな利点の一つである. 一方, 平行な 軟 $\mathrm{X}$ 線を得ることはむずかしく、プロキシミティ露光で ありながら，発散 X 線束を用いる。これは，数次にわた る転写パタンの位置合わせを考劣る上で重要なファクタ である.マスクとウエハを理想的な平面の剛体と仮定し, ウエハ上の多層パタン間の重㸚合わせ䛊差について考察 を加光る。

マスクパタンの $\mathrm{X}$ 線によるウェ八面への投影像の, ウ エハパタンに対する位置ずれは, ウエハに対するマスク の空間的な位置と姿勢の露光レベル間での誤差によって 生じる、いま, マスク, ウェハに関する座標系を図 1 の ように設定する．異なる露光レベル間でのマスクの位置 誤差を $\Delta x, \Delta y, \Delta z$, 姿勢誤差を $\Delta \alpha, \Delta \beta, \Delta \theta$ とすると, 、 スク上の点 $\mathrm{P}(R, \Theta)$ は, 以下の位置ずれをもってウェハ 上の点 $\mathrm{P}^{\prime}$ に投影される. 


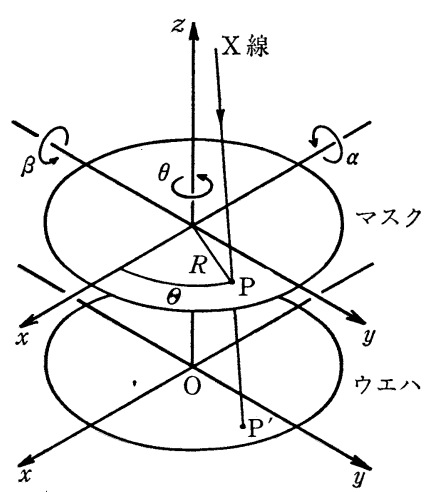

図 1 座標系

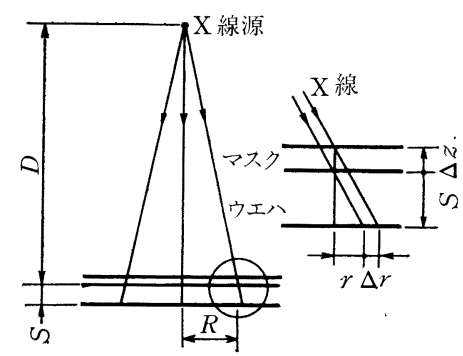

（a）ギャップ変動による位置ずれ（run-out誤差）

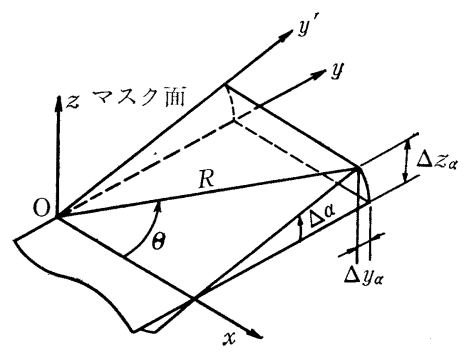

(b) マスクの傾きによる位置ずれ

図 2 マスク, ウエハの幾何学的関係

（1） $\mathrm{X}$ 線光軸に垂直な平面方向の位置䛊差 $\Delta x, \Delta y$ は, そのまま，ウエ八全面にわたって一様な位置ずれを 生じる.

(2) マスクパタンは, 図 2 (a) に示すように, 発散光 束により半径方向に $\boldsymbol{r}$ だけシフトした位置に投影さ れ，プロキシミティギャップを $S$, 線源距離を $D$ と したとき, $r=(R / D) S$ であ. $r$ 自体は位置ずれと はならないが，マスクの位置が露光レベル間で垂直 方向に $\Delta z$ だけ変化すると, 半径方向の位置ずれ

$$
\Delta r_{z}=\frac{R}{D} \Delta z
$$

を生じる。これを, run-out誤差と呼ぶ。

（3）マスクの傾き䛊差 $\Delta \alpha, \Delta \beta$ は, 四 2 (b) に $\Delta \alpha$ につ いて示すように，2種類の位置ずれを引き起こす.
一方は, $\Delta \alpha, \Delta \beta$ に伴って生じるプロキシミティギャ ップ変化による半径方向の位置ずれで,

$$
\begin{aligned}
& \Delta r_{\alpha}=\frac{R}{D} R \sin \Theta \sin \Delta \alpha \fallingdotseq \frac{R^{2} \sin \Theta}{D} \Delta \alpha \\
& \Delta r_{\beta}=\frac{R}{D} R \cos \Theta \sin \Delta \beta \fallingdotseq \frac{R^{2} \cos \Theta}{D} \Delta \beta
\end{aligned}
$$

で表される.他方は, $\Delta \alpha, \Delta \beta$ で $y, x$ 方向に生じるい わゆる cosine 誤差で,

$$
\Delta y_{\alpha}=-R \sin \Theta(1-\cos \Delta \alpha) \fallingdotseq-2 R \sin \Theta\left(\frac{\Delta \alpha}{2}\right)^{2}
$$

$$
\Delta x_{\beta}=-R \cos \Theta(1-\cos \Delta \beta) \fallingdotseq-2 R \cos \Theta\left(\frac{\Delta \beta}{2}\right)^{2}
$$

で表される. $\Delta y_{\alpha}, \Delta x_{\beta}$ は, $\Delta \alpha, \Delta \beta$ についての 2 次の 項であり，他の位置ずれ成分に比べて十分に小さい と考えてよい.

(4) $z$ 軸まわりの回転䛊差 $\Delta \theta$ は, 円周の接線方向に, 半径に比例する位置ずれ

$$
\Delta t=R \Delta \theta
$$

を生じる。

ウエハ上の各点では，以上の位置ずれのベクトル和だ け，パタン位置ずれを生じることになる．合成ベクトル の直交軸成分を $\Delta X, \Delta Y$ として以上の誤差をまとめる と,

$$
\begin{aligned}
\Delta X= & \Delta x+\frac{R \cos \Theta}{D} \Delta z-R \sin \Theta \Delta \theta \\
& +\frac{R^{2} \cos \Theta}{D}(\sin \Theta \Delta \alpha-\cos \Theta \Delta \beta) \\
\Delta Y= & \Delta y+\frac{R \sin \Theta}{D} \Delta z+R \cos \Theta \Delta \theta \\
& +\frac{R^{2} \sin \Theta}{D}(\sin \Theta \Delta \alpha-\cos \Theta \Delta \beta)
\end{aligned}
$$

となり，位置合わせには，6軸の制御が必要である．

これから，以下の性質が明らかとなる.

（1）水平方向の誤差 $\Delta x, \Delta y, \Delta \theta$ に対して, 垂直方向の 誤差 $\Delta z, \Delta \alpha, \Delta \beta$ が引き起こす位置ずれは，パラメー タ $R / D$ 倍だけ小さい. したがって, 水平方向に対 して垂直方向の各制御軸への要求精度は，パラメー タ $R / D$ で決められる值だけ低くなる.

（2） $R$ は，姿勢制御（回転と傾き）への要求精度を示 すパラメータで, 露光面積が大きくなるほど姿勢制 御の重要度が増大する.

（3）位置ずれの現れ方は，ウエハ面内の角度位置に対 して周期的であり， $x, y$ 軸上は, 誤差要因の分離が 
容易な場所である.

これまでの議論は，理想的な平面の試料を仮定して進 めてきたが，実際には，試料は様々のひずみを有してい る. その中で，パタン位置ずれの原因として最も大きい のはプロセスによるウェハの変形である. ウェハ加工プ ロセスでウエハ表面に付着された膜は，その内部応力に よりウエハに反りを与光, 結果としてパタンピッチが変 化する. 例えば, MOS プロセスにおいて, $50 \mathrm{~mm}$ ピッ チで $-0.2 \sim+0.8 \mu \mathrm{m}$ のピッチ変化が報告されてい る6). 反りはプロキシミティギャップの変動をるたらし, ピッチ変化はそのまま位置ずれとなる. このピッチ変化 は, ほぼ等方的なるのとみなせるため, ウェ八面内のピ ッチ変化による位置ずれの 分布は, 式 (1) の run-out 誤 差と等価な性質を有する. したがって, プロキシミティ ギャップの制御によって, ウエハ伸縮に伴う位置ずれの 修正が可能である.

\section{3. 位置合わせ制御法}

ウエハ面内の異なる 3 点で, ウェハパタンに対するマ スクパタン投影像の $x y$ 方向の位置ずれを測定すれば, 式(7),(8)より，6 元連立 1 次方程式

$$
A \boldsymbol{x}=\boldsymbol{b}
$$

が成立する，ここに， $\boldsymbol{x}$ は位置，姿勢の誤差べクトル， $\boldsymbol{b}$ は 3 点で測定された位置ずれベクトル，A は位置ずれ 測定点の配置で決まる係数マトリクスである. $|A| \neq 0$ となるよう配置を選べば, 方程式 (9)は一意に解け, 各軸 方向の誤差成分を完全に分離できる．したがって，上記 位置ずれ測定手段と 6 軸移動機構で，位置合わせ装置を 構成することが可能である.

しかしながら，マスクパタンの X 線投影像の位置測定 は簡単でなく，6 元連立方程式を逐次解きながら制御す る方式は実用的でない，そこで，より単純な装置構成の 可能な制御方式を考える必要がある．先に論じた制御軸 への要求精度を決めるパラメータ $R / D$ は, 通常 0.1 以 下であり，実現精度の観点から垂直方向之水平方向の制 御を分けて考える.

1）プロキシミティギャップ制御法

ウエハ面に対するマスク面の垂直方向の空間的位置と 姿勢は, 異なる 3 点における両者間のギャップ值で一意 に記述できる. そこで, 3 点でマスク, ウェ八間のギャ ップ $s_{1}, s_{2}, s_{3}$ を測定し,

$$
s_{1}=s_{2}=s_{3}=S
$$

という制御を行えば，平行なプロキシミティギャップ $S$ を設定できる，いま，垂直方向に弾性的に支持されたマ スクに，異なる 3 点で個別の変位 $\Delta d_{j}(j=1,2,3)$ を与え

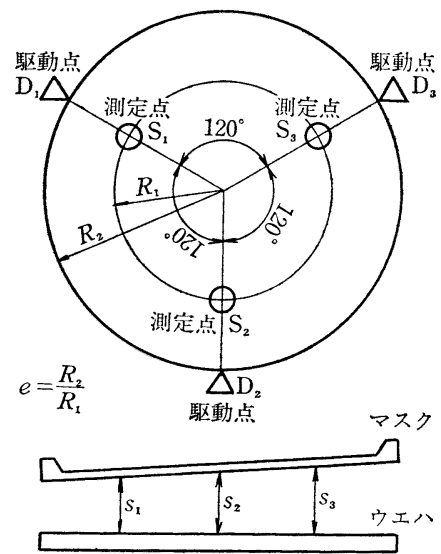

図 3 ギャップ制御の幾何学的関係

ると, 三つの測定点に和ける変位 $\Delta s_{i}(i=1,2,3)$ は,

$$
\Delta s_{i}=\sum_{j=1}^{3} c_{i j} \Delta d_{j}
$$

で表される.ここに， $c_{i j}$ は測定点と駆動点の相対配置 で決まる係数マトリクスである. 式(11)に拈いて， $\Delta s_{i}=$ $S-s_{i}$ とおいてできる 3 元連立方程式を解き,求めた $\Delta d_{j}$ だけ各点を駆動すれば，式(10)の制御が実現される. 図 3 は, 係数マトリクスが最も単純となる測定点, 駆動点の 配置を示す.このとき, 測定点, 駆動点の半径位置の比 $e=R_{2} / R_{1}$ を用いて, 上記連立方程式の解は,

$$
\left(\begin{array}{l}
\Delta d_{1} \\
\Delta d_{2} \\
\Delta d_{3}
\end{array}\right)=\frac{1}{3}\left(\begin{array}{lll}
1+2 e & 1-e & 1-e \\
1-e & 1+2 e & 1-e \\
1-e & 1-e & 1+2 e
\end{array}\right)\left(\begin{array}{l}
S-s_{1} \\
S-s_{2} \\
S-s_{3}
\end{array}\right)
$$

となる。

2）平面方向の位置合わせ制御法

マスクとウェハが平行な間隙をもって対向配置された 状態で, 残る変数 $\Delta x, \Delta y, \Delta \theta$ に関する制御は, フォトリ ソグラフィに括けるマスク合わせと同様で, 種々の方法 が考学られる 7) 9).ここでは, 先に述べたウェハ伸縮に よる位置ずれの補正も考慮する. 前章での考察に基づき, $x y$ 方向位置ずれ测定マークを $x$ 軸上の 2 点 $\mathrm{P}_{\mathrm{L}}\left(R_{0}, \pi\right)$, $\mathrm{P}_{\mathrm{R}}\left(R_{0}, 0\right)$ に配置し, 䛊差要因として $\Delta x, \Delta y, \Delta \theta, \Delta s$ を 考えると, 式 (7), (8) は, 左右測定点 $P_{L}, P_{R}$ で

$$
\begin{aligned}
& \Delta X_{\mathrm{L}}=\Delta x-\frac{R_{0}}{D}(S+\Delta s) \\
& \Delta X_{\mathrm{R}}=\Delta x+\frac{R_{0}}{D}(S+\Delta s) \\
& \Delta Y_{\mathrm{L}}=\Delta y-R_{0} \Delta \theta \\
& \Delta Y_{\mathrm{R}}=\Delta y+R_{0} \Delta \theta
\end{aligned}
$$

と単純化される.ここで, $\left(R_{0} / D\right) S$ は, ウェハマークが 前回の露光レベルで焼き込まれた時の run-outである 


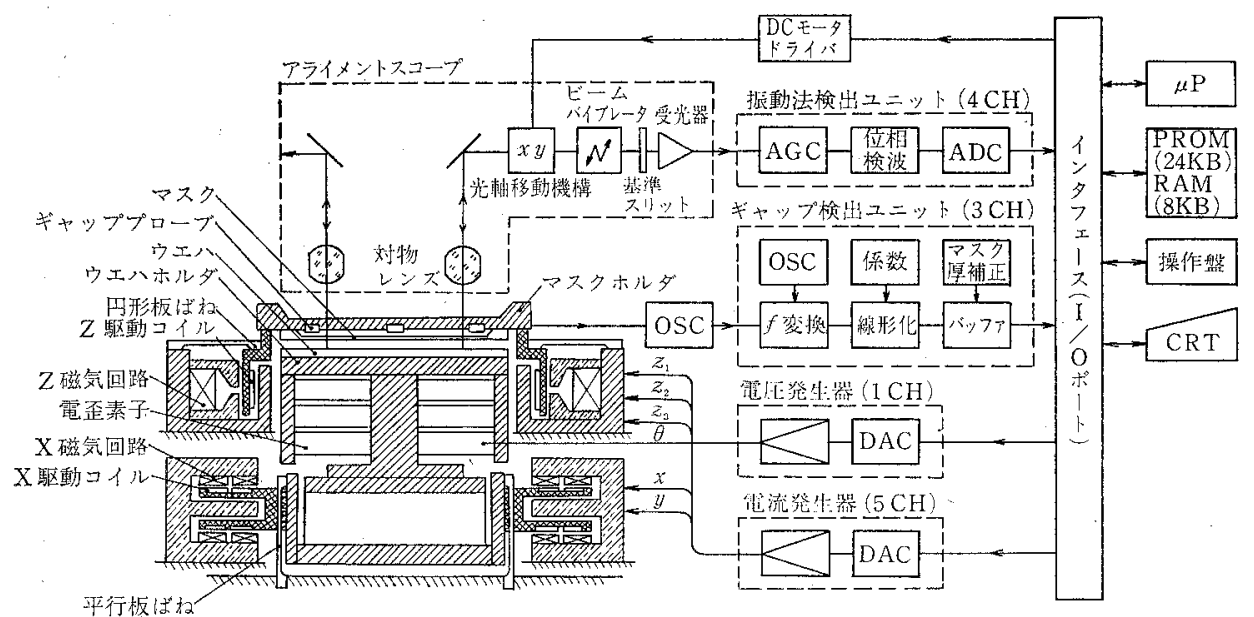

図 4 位置合わせシステムの棈成

が，全露光レッ゙ルでウエハマーク基用す狄ば，( $R_{0} /$

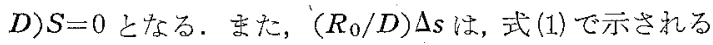
ギャップの変動による run-out 誤庄であるが、マスクマ 一クの位䈯を測る（そのX線による投影像ではない）場 合には, ウ土八伸䁇によるマータピッチ変化に相当する. 以上の条件で式 (13) を解くと，

$$
\left.\begin{array}{l}
\Delta x=\left(\Delta X_{\mathrm{L}}+\Delta X_{\mathrm{R}}\right) / 2 \\
\Delta y=\left(\Delta Y_{\mathrm{L}}+\Delta Y_{\mathrm{R}}\right) / 2 \\
\Delta \theta=\left(\Delta Y_{\mathrm{R}}-\Delta Y_{\mathrm{L}}\right) / 2 R_{0} \\
\Delta s=D\left(\Delta X_{\mathrm{R}}-\Delta X_{\mathrm{L}}\right) / 2 R_{0}
\end{array}\right)
$$

となる、ただし，X線露光に特けるプロキシミティギャ ップは，解像力，転写パタン品質に関係する量である5

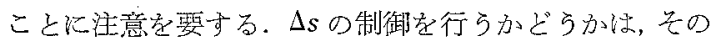
露光レベルに拈ける合わ精度之線幅精度に刘する要求 の度合に応じて半瞇しなければならない。

\section{4. 位置合わせ装置}

\section{1 装置の試作}

図 4 に試作した位置合わせシステムの棈成名示导，装 置はマイクロコンピロータで制御し，前章で考察したア ルゴリズムをソフトウェアで実現する方式とした。

位犆合わ导機搆は，マスク側の3 点駆動 ウエ八側の $x y \theta$ ステージから構成した。各ステージ も板ばねによる完全弾性支持構造で, 駆勘コイルに発生

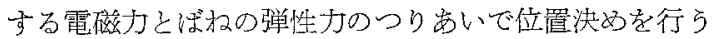
ため，摩擦やバックラッシュがない， $\theta$ ステージで性， 駆動に交流電压を重畳する電圧印加法を用いることで, 電歪素子特有のヒステリシスを除いた。レーザ干涉計に よる測定の結果, 各軸と夕, $0.01 \mu \mathrm{m}$ オーダの移動分解 能を有していだ)。
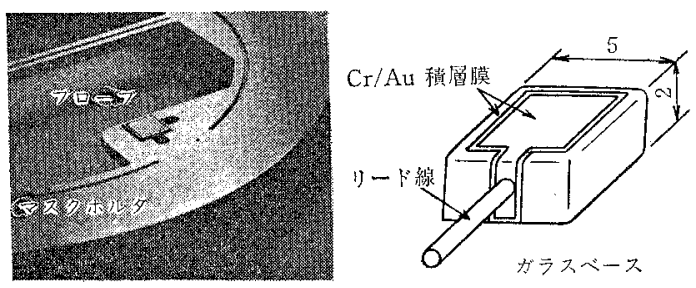

图 5 超小形ギャッププローブ

ギャップ検出には，非接触でかつ高い検出分解能を得 るため, 静電容量方式10）用いた。大氮忡露光4)を行う ためのマスク上方での空間的制約と測定の安定性向上の ために，図 5 に示高超小形プローブを陚作し用いた。 昰 た，本方式は，LC発振の基本或

$$
F=\left\{2 \pi \sqrt{L\left(C_{0}+\varepsilon_{0} A_{0} / s\right)}\right\}^{-1}
$$

$F$ : 発振周波数， $L:$ 発振器のインダクタンス,

$C_{0}$ : 固定容量, $\varepsilon_{0}$ : 真空の誘電率, $A_{0}$ : プロー ブの電極面積

で表される非線形特性を有するたわ，式(15)を $\varepsilon_{0} A_{0} / C_{0} s$ について級数展開して得的当関係式

$$
F_{s=\infty}-F \fallingdotseq F_{s=\infty} \frac{\varepsilon_{0} A_{0}}{2 C_{0}} \cdot \frac{1}{s}
$$

学利用し，图 4 に示寸回路满成で線形化した。試作した ギャップ娭出器とレーザF渉計で，同一物传の変位を同 时测定したとこる，測定值の差の最大值は $0.5 \mu \mathrm{m}$ であ った。

位置ず狆换出は， $\mathrm{Si}_{3} \mathrm{~N}_{4} / \mathrm{SiO}_{2} / \mathrm{Si}_{3} \mathrm{~N}_{4}$ メンブレンのX 線マスク11) が可視光代対して高い透明度をもつことを

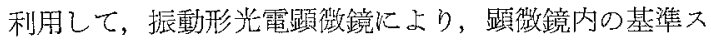
リットとマスク, ウェハのアライメントマーク拡大像

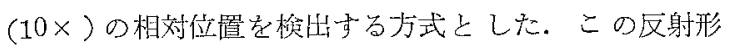




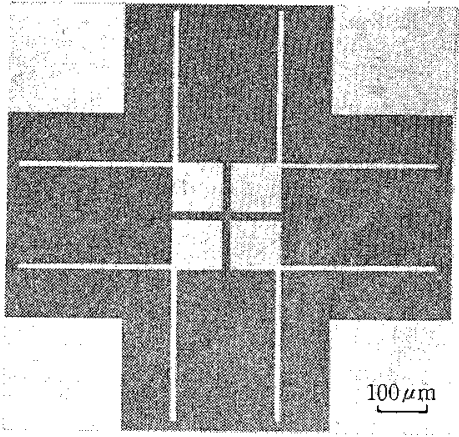

明部は $\mathrm{Au}$ バタン，暗部は透明メンブレン

(a) マスクマーク

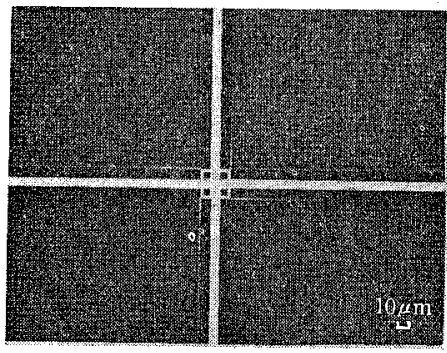

明部は Si主面，暗部は微小くぼみ群

(b) ウエハマーク

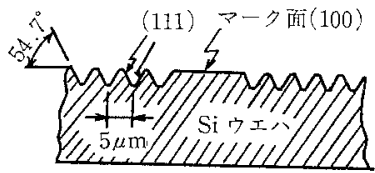

(c) ウエハマーク断耐国

(100)ウエ八の嚗全

中央部：目視笅察用，周迅部：光電検出用 図6 アライメントマーク

検出法12）に打斿精度確保には，アライメントマーク のコントラストが重要で方る。特にウェハマークでは, ウエ八加工プロセスでの表面変化によるコントラスト低 下を防ぐ必要方ある。そこで，異方性エッチングで形状 加工を施したマークを用い, 高コントラストを確保した。 图6にアライタントマークの形状, 構造を示す。 マスク マークのバックグラウンドが暗部となるよら配慮してあ る.図 7 K，本方式で反射率の最悪条件である表面状態 のウエハマークを検出した例を示す。これより，位置ず れがゼロの近傍に扣け石位置愉出分解能は, $0.1 \mu \mathrm{m}$ 以 下である。

\section{2 重ね合わせ精度の評価}

試作した装置の合わせ精度の評価を目的に，露光実験 による転写パタンの位置ずれ测定を行った。ウエハ上に 重䌸露のされたパタン相互の位置ずれには, 装置自体

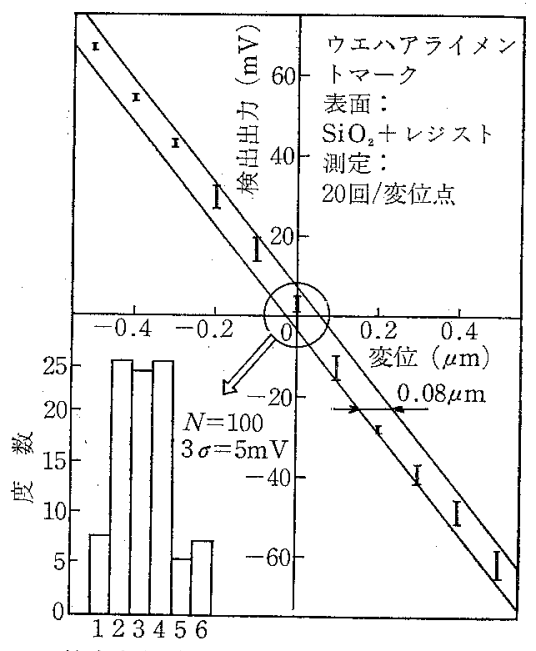

梚出出力 $(\mathrm{mV})$

図 7 マーク検出分解能と検出玨現性

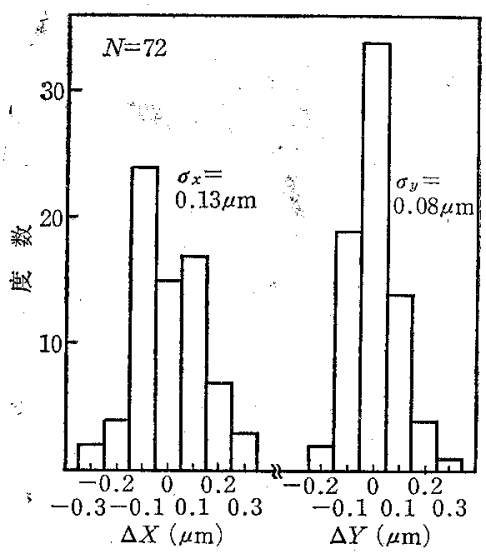

図 8 パダン位置ずれの分布

の合わせ䛊差に加えて, 露光レベル間のマスク愦差, ウ エハひずみ, 平面度不良など，様ふの愦差要因が含まれ る.ここでは装置固有の精度を抽出するため，2 レベル のマスクで1枚のウェハを同一プロセス条件で繰返し露 光することにより試料自体の誤差の影響を除さ，ハタン 合わせ状態の再現性で合わ精度を評価した。

図 8 K,プロキシミティギャップ10 起繰返し，露光ごとにウエハ内の 18 点で测定した位置 ずれの分布を示ず・ばらつきの大ささは， $x$ 方向で $\sigma=$ $0.13 \mu \mathrm{m}, y$ 万方で $\sigma=0.08 \mu \mathrm{m}$ でめった.

さらに詳細な精度評価を行らため,プロキシミティギ ナップの設定值を変えた 3 回の露光を加光，䛊差要因の 分離を行った。 表 1 は, ウエハ内3 点での位置ずれデー 夕を組合子せて式(9)の6元連立方程式を解き，装置の 制御軸に対応する誤差を分離した結果である， $R / D=$ 
表 1 分離された詿差要因

\begin{tabular}{l|c|r|r|r|r|r|r}
\hline No. & $\begin{array}{c}\text { ギャッ } \\
(\mu \mathrm{m})\end{array}$ & $\begin{array}{c}\Delta x \\
(\mu \mathrm{m})\end{array}$ & $\begin{array}{c}\Delta y \\
(\mu \mathrm{m})\end{array}$ & $\begin{array}{c}\Delta z \\
(\mu \mathrm{m})\end{array}$ & $\begin{array}{c}\Delta \theta \\
(\mu \mathrm{rad})\end{array}$ & $\begin{array}{c}\Delta \alpha \\
(\mathrm{mrad})\end{array}$ & $\begin{array}{c}\Delta \beta \\
(\mathrm{mrad})\end{array}$ \\
\hline 1 & 10 & -0.16 & 0.06 & 0.5 & -2.3 & -0.01 & 0.12 \\
2 & 10 & 0.04 & 0.01 & -0.6 & -0.8 & -0.21 & -0.34 \\
3 & 10 & -0.13 & -0.06 & 1.2 & 1.0 & -0.01 & 0.15 \\
4 & 10 & -0.02 & 0.00 & -1.3 & 2.3 & 0.22 & 0.09 \\
5 & 20 & -0.02 & 0.15 & 9.9 & 3.0 & 0.08 & -0.15 \\
6 & 30 & 0.10 & 0.28 & 17.0 & 5.3 & 0.41 & 0.04 \\
7 & 40 & -0.13 & 0.13 & 28.5 & -4.1 & 0.26 & 0.46 \\
\hline
\end{tabular}

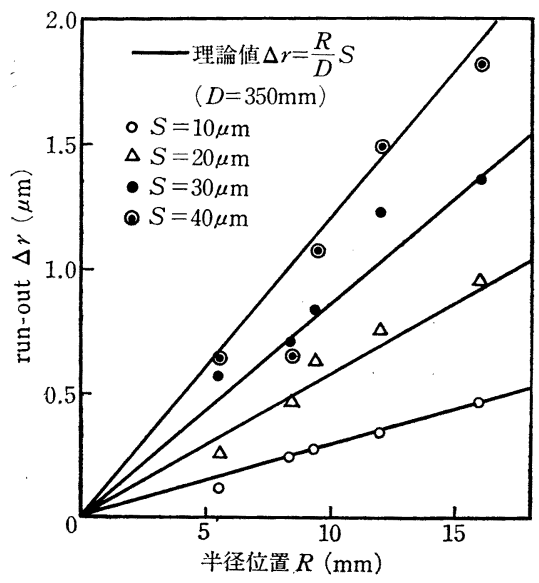

图 9 プロキシミティギャップの一様性

0.1 を考慮すると, 各制御軸とも位置ずれに対してほぼ 均等な影響度であるが，マスクの傾きが比較的大きい。 これは，試料の平面度不良の影響であろう．図 9 は，ウ エハ内の同一半径位置で同一ギャップを仮定し, 種々の 同心円上にある 3 点の位置ずれデータから run-out 量を 求めて半径 $R$ に対してプロットしたものである. 理論值 と測定值は比較的良い一致を示しているが，ここでも， 試料の平面度不良の影響が見られる。

以上の結果から，試作した装置は $\pm 0.2 \mu \mathrm{m}$ 以下の重 ね合わせ精度を持ち， $1 \mu \mathrm{m}$ ルールの VLSI のリソグラ フィに適用可能な性能を有していると考えられる.

\section{5. ま と め}

VLSI 実現のための X 線露光法への適用を目的に, マ スクとウェハの高精度位置合わせ法について検討し，以 下の結論を得た。

（1） X 線露光におけるパタン位置ずれ誤差要因につい て解析し，位置合わせ制御の要求条件を明らかにし た.

(2) 3 点の ギャップ計測 と $x y$ 方向各 2 点の マスク, ウエハ相対位置計測による 6 軸位置合わせ制御法を
提示した.

（3）弾性支持 6 軸微動機構, 静電容量形ギャップ測 定方式，拉よび高コントラストアライメントマー クの反射形位置検出方式を組合わせて，高精度位 置合わせ装置を開発した。

（4）試作装置のパタン重ね合わせ精度を露光実験に より評価し，合わせ精度 $\pm 0.2 \mu \mathrm{m}$ を得た。

ここで開発した位置合わせ装置は, 既にX 線源と組 合わせて，半導体デバイスの試作プロセスに供せられ ている. 今後は, サブミクロンパタンの転写を可能と する位置合わせ精度の実現が目標である．大面積の一括 露光法では試料の平面度向上, 装置としてはステップア ンドレピートシステムの実現が課題となろう.

おわりに，本研究遂行にあたり指導，助言をいただい た当所山崎特殊加工研究室長, 中山調查役, 日本通信技 術(株)大塚調査役，ならびに装置製作に協力いただいた 日本光学工業(株)に対し，謝意を表します.

\section{文献}

1) D. L.Spears and H.I.Smith: High Resolution Pattern Replication Using Soft X-Rays, Electron Lett., 8, 4, (1972) 102.

2) J. H. McCoy and P.H. Sullivan: Mask Alignment for the Fabrication of Integrated Circuits Using X-Ray Lithography, Solid State Technol., Sept. (1976) 59.

3) D.C. Flanders and H.I.Smith: A New Interferometic Alignment Technique, Appl. Phys. Lett., 31, 7, (1977).

4) S. Yamazaki, S. Nakayama, T. Hayasaka and S. Ishihara: X-Ray Exposure System Using Finely Position Adjusting Apparatus, J. Vac. Sci. Technol., 15, 3, (1978) 987.

5）中山 了, 早坂東亚, 山崎新一：X線投影露光法, 研究 実用化報告, 27, 9 (1978) 210 .

6) L. D. Yau: Correlation between Process-induced Inplane Distortion and Wafer Bowing in Silicon, Appl. Phys. Lett., 33, 8, (1978) 756.

7）大島康次郎：マイクロサーボ, 計測と制御, 14, 12 (1975) 22.

8）石原 直, 竹内信行, 吉田和衛：マスク, ウエ八位置合 わせの自動制御, 昭和 51 年度精機学会秋季大会学術講 演会前刷 (1976) 357 .

9）平賀亮三, 鈴木章義, 奥津和久：自動マスク合わせ装置, 半導体・集積回路技術第 13 回シン ポジゥム論文集, 7 (1977) 42.

10）川口英太郎ほか：微小ギャップ測定方式の検討，昭和 52 年度精機学会秋季大会学術講演会前刷 (1977) 167 .

11) T. Kadota et al. : Preparation of $X$-Ray Lithography Masks with Large Area Sandwich Structure Membrane, J.J.A. P., 17, 8, (1978) 1447.

12）石原 直ほか：反射形マークによる位置検出法, 昭和 53 年度精機学会秋季大会学術講演会前刷 (1978) 427. 